\title{
Gestation Rate in Beef Cows with Different Calving Orders Submitted to FTAI Protocol: Effects of Body Condition, Number of Progesterone Intravaginal Device Uses and Bull
}

Lucas Balinhas Farias (Corresponding Author), Matheus Wrege Meireles Barbosa, Matheus Gomes Lopes, Gabriel Weizenmann Fernandes, Ana Laura Aita Xavier, Gustavo Fischer, Cássio Cassal Brauner

Faculdade de Agronomia Eliseu Maciel-Universidade Federal de Pelotas. CEP 96010-900 Capão do Leão, RS, Brazil

Received: May 9, 2020

doi:10.5296/jas.v8i2.17002
Accepted: June 23, 2020 Published: June 28, 2020

URL: https://doi.org/10.5296/jas.v8i2.17002

\begin{abstract}
The search for better reproductive rates in beef cattle breeding must consider some important issues, such as nutrition, health, animal category, type of reproductive technique, and selection of animals. Thus, the objective of this study was to evaluate the effect of the body condition score (BCS), the number of uses of the intravaginal progesterone device and the effect of the bull on the gestation rate of lactating beef cows, with different calving orders, submitted to a fixed timed artificial insemination (FTAI) protocol. In the study, 623 Aberdeen Angus cows were used, which were categorized into three groups according to the calving order: primiparous cows, second-parity cows, and multiparous cows. On day zero of the FTAI protocol, an evaluation of the BCS of the cows was performed, using progesterone intravaginal devices (IVD) for 9 days, starting from the D0 of the protocol both for used and new IVD. Semen from three different Aberdeen Angus breeders was used. Statistical analysis was made in the NCSS 7.0 software, using the Chi-square test and a significance value of $\mathrm{p}<0.05$. The calving order influenced the pregnancy rate, with the category of primiparous cows having the lowest rates $(\mathrm{p}<0.05)$. The BCS and the number of uses of the IVD showed significance only in the primiparous category, in which animals with BCS equal or above 3.5 obtained a higher pregnancy rate, as well as animals with second-use IVD when compared to other groups $(\mathrm{p}<0.05)$. Therefore, primiparous cows presented a lower pregnancy rate when compared to the other categories, as well as the BCS and the number of uses of the IVD.
\end{abstract}


Keywords: beef cattle, body condition score, estrus synchronization, pregnancy rate, reproductive biotechnology

\section{Introduction}

Protocols for estrus induction and ovulation synchronization have facilitated the use of artificial insemination, as a consequence, accelerate the genetic progress of herds (Lucy, 2001). In 2002, only $6 \%$ of dams were submitted to some artificial insemination protocol. In 2018, the number of FTAI reached 13.3 million procedures, indicating that $86 \%$ of the inseminations were carried out by FTAI in Brazil. The FTAI has grown 130 times in the last 16 years, bringing great advances and benefits for beef and dairy cattle.

Several factors influence the reproductive performance of beef cattle, such as mating season, body condition, bull fertility, and nutritional management (Campos et al., 2005). The nutritional status of cows in the postpartum period affects the pregnancy rate, as it interferes with the growth of the dominant follicle, ovulation, and fertility, having a direct effect on GnRH and pituitary gonadotropins, and indirectly on the somatotropic axis (Diskin et al., 2003). Besides interfering in the growing and development of younger animals, as primiparous cows, which require greater nutritional support due to the combined effect of their growth and first lactation, which leads to low reproductive efficiency of these animals when subjected to periods of food restriction (Spitzer et al., 1995). The body condition score (BCS) is a visual measure used worldwide to monitor the nutritional status and the reproductive performance of dams because it is a determining coefficient in the redesign and the general productivity of the herd, besides being practical and of low cost (Lake et al., 2005).

Many hormones are used in an ovulation synchronization protocol, among them there is the progesterone. The use of progesterone-controlled release devices in the vaginal epithelium in association with estrogens causes follicular regression and the beginning of a new follicular wave (Pratt et al.,1991). The purpose of the device is to maintain supraluteal progesterone levels (Baruselli et al., 2006), to increase the fertility until the first estrus (Patterson et al, 1995) and induce the ovulation in non-cyclical cows (Rhodes et al., 2002; Wheaton and Lamb, 2007). When the progesterone intravaginal device (IVD) is removed, drop-in progesterone levels occur, allowing final follicle development and ovulation (Carvalho et al, 2004).

Cows with normal metabolism have progesterone plasma levels during the estrous cycle below 1ng/ml and maximum values between 2.3ng/ml for Zebu breeds (Agarwal et al., 1977), therefore progesterone IVD are expected to maintain supraluteal progesterone levels, which means above $1 \mathrm{ng} / \mathrm{ml}$. The protocols are normally applied in random periods during the estrous cycle or in the anestrous period, and to have greater assertiveness in the use of progesterone we must guarantee its minimum dosage exogenously. The progesterone IVD use with more than one use is being more studied in Brazil because it reduces the cost of a synchronization protocol, however, we must investigate if both hormonal doses are adequate to all categories, not interfering the herd fertility. 
Colazo et al. (2004), when submitting crossed Angus heifers to synchronization reported that fertility, after the FTAI protocol, of these animals, does not differ when synchronized with new or reused progesterone IVD, but decreases when synchronized with reused progesterone IVD twice, being $49,6 \%, 48 \%$ and $45.6 \%$ in the pregnancy rate, respectively. Barufi et al. (2002) when evaluating the gestation rate of calving Nellore cows, with a high rate of anestrus, synchronized with new and reused progesterone IVD, found no difference, reporting $28.8 \%$ and $38.7 \%$ in the pregnancy rate, for IVD of new and reused progesterone, respectively.

In beef cattle breeding, it is known that the calving order is a factor that influences the pregnancy rate (Grillo et al., 2015), in which primiparous cows have gestation rate around $15 \%$ in the lactation period, and multiparous cows - more than two pregnancies - around $25 \%$ in the same period (Jaume and Moraes, 2002). Primiparous cows, especially, must receive a greater nutritional supply so that they are successful in maintaining pregnancy, do not interrupt their growth and so that they can conceive in the later reproductive period (Pilau and Lobato, 2009). Second-parity cows are a category not much studied yet, because in many cases they are considered multiparous cows. However, heifers starting to reproduce earlier, in addition to being important to the primiparous, the second-parity cows are also a challenged category, demanding care regarding their nutritional requirements, especially during the mating period.

Another factor directly related to good reproductive rates is the semen quality used in FTAI (Silva et al., 2015). Low-quality semen may harm the results in a FTAI protocol (Januskauskas et al., 2001; Severo, 2009). According to Colégio Brasileiro de Reprodução Animal (C.B.R.A., 2013), the semen must follow some criteria to be commercialized and used in AI and FTAI, among these are progressive motility, vigor, morphological defects and sperm concentration per reed. Thus, several factors determine the fertilization capacity of sperm, such as the ones intrinsic to sperm and seminal plasma components. (Parisi et al., 2014; Kaya et al., 2016).

This study hypothesizes that primiparous cows, second-parity cows, and multiparous cows present different pregnancy rates according to the body condition score and the type of progesterone implant used (new or reused once), and that bulls present different results in the same animal category. Thus, the purpose of this study is to evaluate the body condition score (BCS) effect, the use of a progesterone implant, and the effect of bulls in the gestation rate of lactating beef cows, with different calving order, submitted to FTAI protocol.

\section{Materials and Methodology}

This experiment was conducted during the 2017/2018 breeding season, spring-summer, at a commercial beef cattle farm located at the interchange of access to Piratini city, in the state of Rio Grande do Sul, Brazil, at the coordinates: -31, 7357498, -52.9987845. A total of 623 Aberdeen Angus beef cows participated in the study. On day zero of the FTAI protocol was made a BCS evaluation in the cows, in which the animal with BCS 1 was considered severely thin, and the animal with BCS 5 was classified as obese (Ayres et al., 2009). 
The cows were kept in a native field having a characteristic natural association of forage species, composed of a mixture of bahia grass (Paspalum notatum), louisiana grass (Axonopus affinis), ryegrass (Lolium multiflorum spp.) and some clover species (Tripholium spp.) and with access to water ad libitum. The animals were categorized according to their calving order in primiparous (first calving cows with an average age of 23 months), second-parity cows (second calving cows with an average age of 32 months) and multiparous (adult cows with three or more calves and over 41 months of age).

The synchronization protocol used for all animals was: D0 IVD progesterone $1.00 \mathrm{~g}$ (Primer®) for first or second use (New or Reused), randomly distributed among cows, and application of $2.00 \mathrm{mg}$ of benzoate of estradiol (BE) (RIC-BE®) intramuscularly (IM); on the seventh day (D7) $0.15 \mathrm{mg}$ of D-cloprostenol (Estron ${ }^{\circledR}$ ) was applied via IM; removal of IVD, application of estradiol cypionate (EC) (ECP®) via IM and 400 IU equine chorionic gonadotropin (eCG) (syncro eCG®) via IM occurred on day 9 (D9) and 48 hours after (D11) FTAI occurred. Insemination was carried out by two inseminators (Inseminator A and B), randomly distributed among the animals, which did not influence the pregnancy rates.

The semen used was from three breeders of the Aberdeen Angus (Bull A, B, and C), distributed homogeneously among the cows. These met the minimum requirement of the Colégio Brasileiro de Reprodução Animal, meaning 35\% of progressive sperm motility and a maximum of $20 \%$ of abnormal total sperm after thawing (C.B.R.A, 2013).

The pregnancy diagnosis was made with transrectal ultrasound, 30 days later FTAI, using a portable device (Mindray DP220, Shenzhen, China), coupled to a 5MHz linear transducer. The gestation was characterized through the view of the embryo with the heart beating and the pregnancy rate was defined as the number of cows divided to the number of cows submitted to FTAI.

The statistical analysis was made with NCSS 7.0 (2007) software. The data were analyzed using the Chi-square test, choosing a significance level of $5 \%$, with pregnancy rate expressed in absolute frequency and simple percentage.

\section{Results and Discussion}

According to the results presented on table 1, the calving order is a determining factor to the gestation rate in caws submitted to FTAI protocol, in which the primiparous category had the lower rate when compared to second-parity cows and multiparous cows, $(47.1 \%),(67.3 \%) \mathrm{e}$ (68.9\%), respectively $(\mathrm{P}<0.05)$. Corroborating with Grillo et al., (2015), who evaluated the reproductive efficiency of Nellore cows submitted to FTAI protocol and demonstrated that first-calf cows obtained lower pregnancy rates when compared to heifers and multiparous cows $(45.3 \%),(86 \%)$ e $(76.8 \%)$, respectively. This low primiparous pregnancy rate is directly related to the fact that this is the herd's most demanding category because, despite the reproduction, they are also in a growing phase, which requires great nutritional requirements (Franco et al. 2016). Another sub-hypothesis related to this study was that the second-parity cows' category would present an intermediate result between the two other categories, closer to the primiparous, which would require more control and attention in the nutritional 
management. However, the second-parity cows presented the same gestational rate as the multiparous cows, evidencing the great importance of concentrating efforts on the management of primiparous cows for the gestational repetition, and after this moment these animals decrease their needs for growth, without reducing the impact on subsequent reproductive cycle performance.

Primiparous cows with BCS from 3 to 3.5 obtained pregnancy rate lower than second-parity cows and multiparous cows $(\mathrm{P}<0.05)$, with the same body condition scores (Table 1$)$, pointing out the great nutritional need of primiparous cows, because even presenting the equal BCS results of the other categories, obtained lower gestational rate. Thus, obtaining high pregnancy rates in primiparous cows is a challenge for beef cattle, and separate management of these categories is recommended (Lobato et al., 2010).

Table 1. Value of pregnancy rate of cows submitted to FTAI protocol according to the calving order and body condition score (BCS), with distribution absolute (n) and relative (\%)

$$
\mathrm{BCS}+(\mathrm{n})
$$

Calving order

Average

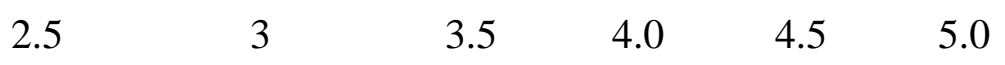

\begin{tabular}{|c|c|c|c|c|c|c|c|}
\hline Primiparous & $\begin{array}{c}17.6 \% \\
(17)\end{array}$ & $36.8 \%^{\mathrm{b}}(38)$ & $\begin{array}{c}51.3 \%{ }^{b} \\
(39)\end{array}$ & $\begin{array}{c}64.3 \% \\
(28)\end{array}$ & $\begin{array}{l}60 \% \\
(15)\end{array}$ & $\begin{array}{c}66.7 \% \\
(3)\end{array}$ & $\begin{array}{r}47.1 \% \\
(140)\end{array}$ \\
\hline Second-parity & $60 \%(10)$ & $60.7 \%^{\mathrm{a}}(28)$ & $\begin{array}{c}76.9 \%{ }^{\mathrm{a}} \\
(39)\end{array}$ & $\begin{array}{l}64 \% \\
(50)\end{array}$ & $\begin{array}{c}61.8 \% \\
(34)\end{array}$ & $\begin{array}{l}90 \% \\
(10)\end{array}$ & $\begin{array}{c}67.3 \% \\
(171)\end{array}$ \\
\hline Multiparous & $25 \%$ & $69 \%^{a}(29)$ & $\begin{array}{c}69 \%{ }^{\mathrm{a}} \\
(58)\end{array}$ & $\begin{array}{c}67.4 \% \\
(86)\end{array}$ & $\begin{array}{c}77.4 \% \\
(84)\end{array}$ & $\begin{array}{c}66.7 \% \\
(42)\end{array}$ & $\begin{array}{c}68.9 \% \\
(312)\end{array}$ \\
\hline$P$ & 0.06 & 0.022 & 0.04 & 0.90 & 0.13 & 0.33 & $<0.0001$ \\
\hline
\end{tabular}

a, b Average in the column, followed by different letters are different $(\mathrm{P}<0.05)$. " $\mathrm{n}$ " means sample quantity of animals within the BCS x calving order criteria.

According to the data presented in table 2, it is observed that primiparous cows with BCS equal o superior to 3.5 have higher pregnancy rates than animals from the same category with BCS less than $3.5(\mathrm{P}<0.05)$. In the case of second-parity and multiparous cows, the BCS has not been shown to affect the pregnancy rate $(\mathrm{P}>0.05)$. The $\mathrm{BCS}$, together with weight, are related to cyclical ovarian recovery with a consequent positive impact on the conception rate (Sawyer et al., 1991). Another factor that contributes to the lower pregnancy rate of primiparous cows is that they have a longer average anestrus time, 20 to 30 days longer than 
that of multiparous cows (Meneghetti and Vasconcelos, 2008).

Lalman et al. (1997), in an experiment restricting the feeding of primiparous Angus cows to reduce the $\mathrm{BCS}$ at calving, they observed that the animals with feeding restriction at calving took 121 days for the return of the first luteal phase and concluded that the BCS at calving was the most important factor for the anestrous period of primiparous cows, in agreement with this study, in which primiparous cows with BCS below 3.5 obtained lower pregnancy rates than cows with BCS equal to or greater than 3.5.

Table 2. Percentage of pregnancy rate of cows submitted to FTAI protocol, according to the condition scores grouped in less than or equal to $3(\leq 3.0)$ and greater than or equal to 3.5 $(3.5 \leq)$, with distribution absolute $(\mathrm{n})$ and relative $(\%)$

\begin{tabular}{cccc}
\hline & \multicolumn{2}{c}{ BCS \% (n) grouped } & $P$ \\
Calving order & $\leq 3.0$ & $3.5 \leq$ & \\
\cline { 2 - 3 } & $30.9 \%^{\mathrm{b}}(55)$ & $57.6 \%^{\mathrm{a}}(85)$ & 0.001 \\
Primiparous & $60.5 \%(38)$ & $69.2 \%(133)$ & 0.31 \\
Second-parity & $56.1 \%(41)$ & $70.7 \%(271)$ & 0.059 \\
\hline
\end{tabular}

a, b Average, on the line, followed by different letters are different $(\mathrm{P}<0.05)$ " $\mathrm{n}$ " means sample quantity of animals within the criteria BCS x calving order.

The data showed on table 3 elucidate that there was no effect of the bulls on the pregnancy rate $(\mathrm{P}>0.05)$ of cows submitted to FTAI protocol. These data collaborate with Farias et al. (2018), in which 216 Braford cows were subjected to the FTAI protocol with two different bulls and they did not interfere in the pregnancy rate.

However, Schenatto et al. (2016) e Luz et al. (2018) observed the influence of the bull used in FTAI and concluded that the choice of bulls proved to the technic is a fundamentally important factor to obtain great productive results. Thus, tests are important to determine with certainty the bulls which may have greater performance in FTAI programs, because, as observed by these authors, bulls with approved sperm quality can present different results in the FTAI. 
Table 3. Influence of the bull on the pregnancy rate submitted to the FTAI protocol, according to the calving order, with absolute (n) and relative (\%) distribution

\section{BULL}

Calving order

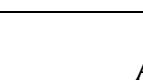

A

B $\quad$ C

$P$

\begin{tabular}{ccccc}
\hline Primiparous & $59.5 \%(37)$ & $39.7 \%(57)$ & $45.8 \%(46)$ & 0.187 \\
Second-parity & $74.4 \%(39)$ & $62.5 \%(72)$ & $68.3 \%(60)$ & 0.435 \\
Multiparous & $71.4 \%(13)$ & $68.4 \%(126)$ & $73.1 \%(173)$ & 0.602 \\
\hline
\end{tabular}

${ }^{\mathrm{a}, \mathrm{b}}$ Average, on the line, followed by different letters are different $(\mathrm{P}<0.05)$ " $\mathrm{n}$ " means sample quantity of animals within the criteria bull $\mathrm{x}$ calving order.

The objective of the controlled progesterone release IVD is to keep the supraluteal progesterone levels (Baruselli et al., 2006), to increase fertility until the first estrus (Patterson et al., 1995) and to induce ovulation in non-cyclical cows (Rhodes et al., 2002; Wheaton and Lamb, 2007). Previous studies (Figueredo et al., 2019; Buralli et al., 2019, Cavalieri et al., 2019) evaluating the possibility to reuse the progesterone IVD in second-parity cows and multiparous cows presented controversial results. In this study, it was not observed the difference in using once or twice the progesterone IVD to second-parity and multiparous cows $(\mathrm{P}>0.05)$. According to the results presented in table 4, corroborating with Melo et al. (2012) who likewise found no difference, using progesterone IVD (CIDR®). However, these results differ from those found by Colazo et al. (2004) and Souza et al. (2015) in which they observed a difference between the categories using the CIDR ${ }^{\circledR}$ progesterone IVD, as well as Pereira et al. (2018) using the progesterone IVD (DIB®). The divergencies can be explained due to the physiological differences from possible stages of the estrous cycle in which the animals were, as well as the residual load present in the IVD. Intravaginal progesterone-controlled devices may have different doses of progesterone in CIDR $(1.9 \mathrm{~g}$ of progesterone per device), which is higher than that used in PRIMER ${ }^{\circledR}$ and DIB $®(1.0 \mathrm{~g}$ per device) which explains the difference found by Pereira et al. (2018), which disagrees with the present study since the DIB ${ }^{\circledR}$ progesterone IVD also contains $1.00 \mathrm{~g}$ of progesterone. Progesterone IVDs that are the same in the first use, however, they may differ in their residual concentrations in the second, since they release more progesterone when used in animals with low endogenous concentrations, resulting in less residual progesterone after the first use (Neri et al., 2015).

In this study, it was observed the difference in the pregnancy rate in primiparous cows, in which the animals that received the reused-progesterone IVD presented a greater pregnancy rate than the ones which received a new implant $(\mathrm{P}<0.05)$. The excess of circulating progesterone decreases the frequency of LH pulses, which are essential in follicular development (Roberson et al., 1989) and these low frequencies decrease the development of 
the dominant follicle (Martin, 1984). The size of the dominant follicle is closely related to the ovulation and conception rates (Meneghetti et al., 2009; Lopes et al., 2007), with larger follicles giving rise to larger corpus luteum and, consequently, it is related to lower rates of embryonic resorption, as they are more released increased progesterone production (Perry et al, 2005; Perry et al, 2007).

Table 4. Influence of the use of new progesterone IVD or already used once $(1 \mathrm{x})$ on the pregnancy rate of cows submitted to the FTAI protocol, according to the calving order, with absolute (n) and relative (\%) distribution

\begin{tabular}{cccc}
\hline \multirow{2}{*}{ Calving Order } & \multicolumn{2}{c}{ Implant $+(\mathrm{n})$} & $P$ \\
\cline { 2 - 3 } & New & $1 \mathrm{x}$ & \\
\hline Primiparous & $40.62 \%^{\mathrm{b}}(96)$ & $61.4 \%^{\mathrm{a}}(44)$ & 0.02 \\
Second-parity & $64.6 \%(127)$ & $75.0 \%(44)$ & 0.20 \\
Multiparous & $73.2 \%(127)$ & $65.9 \%(185)$ & 0.17 \\
\hline
\end{tabular}

a, b Average, on the line, followed by different letters are different $(\mathrm{P}<0.05)$ " $\mathrm{n}$ " means sample quantity of animals within the criteria implant $\mathrm{x}$ calving order.

\section{Conclusion}

Primiparous lactating beef cows presented a lower gestation rate comparing to the second-parity cows and the multiparous cows, being the body condition the key factor for reproductive success. Also, primiparous have better results in the FTAI protocol when the second-use progesterone IVD is used. There is no effect of the bull on the gestation rate according to the categories of breeding females. Therefore, there are important differences in the reproductive performance of beef cows according to the category, mainly with higher demands on primiparous. Second-parity and multiparous cows perform equally.

\section{References}

Agarwal, S. P. et al. (1977). Studies on steroid hormones: Progesterone concentration in the blood serum of zebu cows during oestrous cycle. Indian Journal of Animal Sciences, 42(11), 715-719.

Ayres, H. et al. (2009). Validation of body condition score as a predictor of subcutaneous fat in Nelore (Bos indicus) cows. Livestock Science, 123(2-3), 175-179. https://doi.org/10.1016/j.livsci.2008.11.004

Barufi, F. B. et al. (2002). Sincronização do estro e da ovulação em bovinos de corte com Crestar, CIDR ou CIDR reutilizado, seguidos ou não pela administração de eCG. Revista Brasileira de Reprodução Animal, 26(3), 226-229. 
Baruselli, P. S. et al. (2006) Impacto da IATF na eficiência reprodutiva em bovinos de corte. Simpósio Internacional de Reprodução Animal Aplicada, 2, 113-132.

Buralli, P. H. B. et al. (2019). Uso de implantes reutilizáveis de progesterona: uma biotecnologia reprodutiva sustentável. Revista Valore, 4, 324-335.

Campos, W. E. et al. (2005). Manejo reprodutivo em gado de corte. Embrapa Cerrados-Documentos (INFOTECA-E). [Online] Available: https://www.infoteca.cnptia.embrapa.br/infoteca/handle/doc/544626 (July 23, 2019)

Carvalho, J. B. P. D. (2004). Sincronização da ovulação com dispositivo intravaginal de progesterona (CIDRÂA) em novilhas Bos indicus, Bos indicus $x$ Bos taurus e Bos taurus (Doctoral dissertation, Universidade de São Paulo).

Cavalieri, F. L. B. et al. (2019). Effects of a reusable progesterone device on conception rates and estrus cycle re-synchronization in Nelore cows. Semina: Ciências Agrárias, 40(6Supl3), 3501-3510. https://doi.org/10.5433/1679-0359.2019v40n6Supl3p3501

Colazo, M. G. et al. (2004). Fertility in beef cattle given a new or previously used CIDR insert and estradiol, with or without progesterone. Animal Reproduction Science, 81(1-2), 25-34. https://doi.org/10.1016/j.anireprosci.2003.09.003

COLÉGIO BRASILEIRO DE REPRODUÇÃO ANIMAL, C. B. R. A. (2013). Manual para Exame Andrológico e Avaliação de Sêmen Animal (3. Ed). Belo Horizonte, 104.

Diskin, M. G. et al. (2003). Effects of nutrition and metabolic status on circulating hormones and ovarian follicle development in cattle. Animal Reproduction Science, 78(3-4), 345-370. https://doi.org/10.1016/S0378-4320(03)00099-X

Farias, L. B., De Freitas, J. R. P., \& Brauner, C. C. (2018). Avaliação do efeito do touro e da condição corporal na taxa de prenhez de vacas submetidas ao protocolo de inseminação artificial em tempo fixo. Revista Científica Rural, 20(2), 305-313. https://doi.org/10.30945/rcr-v20i2.275

Figueredo, V. C. S. et al. (2019). Efeito do implante intravaginal de progesterona na taxa de prenhez de novilhas Nelore/Effect of intravaginal progesterone implantation on the pregnancy rate of Nellore heifers. Brazilian Journal of Development, 5(11), 24291-24295. https://doi.org/10.34117/bjdv5n11-116

Franco, G. L., Faria, F. J. C., \& D’oliveira, M. C. (2016). Interação entre nutrição e reprodução em vacas de corte. Informe Agropecuário, Belo Horizonte, 37(292), 36-53.

Grillo, G. F. et al. (2015). Comparação da taxa de prenhez entre novilhas, primíparas e multíparas da raça Nelore submetidas à inseminação artificial em tempo fixo. Brazilian Journal of Veterinary Medicine, 37(3), 193-197.

Januskauskas, A., Johannisson, A., \& Rodriguez-Martinez, H. (2001). Assessment of sperm quality through fluorometry and sperm chromatin structure assay in relation to field fertility of frozen-thawed semen from Swedish AI bulls. Theriogenology, 55(4), 947-961. 
https://doi.org/10.1016/S0093-691X(01)00456-3

Jaume, C. M., \& Moraes, J. C. F. (2002). Importância da condição corporal na eficiência reprodutiva do rebanho de cria. Embrapa Pecuária Sul-Documentos (INFOTECA-E). [Online] Available: https://www.infoteca.cnptia.embrapa.br/infoteca/handle/doc/227716 (July 23. 2019)

Kaya, S. et al. (2016). Determination of ceruloplasmin, some other acute phase proteins, and biochemical parameters in cows with endometritis. Veterinary World, 9(10), 1056. https://doi.org/10.14202/vetworld.2016.1056-1062

Lake, S. L. et al. (2005). Body condition score at parturition and postpartum supplemental fat effects on cow and calf performance. Journal of Animal Science, 83(12), 2908-2917. https://doi.org/10.2527/2005.83122908x

Lalman, D. L. et al. (1997). Influence of postpartum weight and body condition change on duration of anestrus by undernourished suckled beef heifers. Journal of Animal Science, 75(8), 2003-2008. https://doi.org/10.2527/1997.7582003x

Lobato, J. F. P., Menegaz, A. L., \& Pereira, A. C. G. (2010). Pre-and post-calving forage systems and reproductive performance of primiparous cows. Revista Brasileira de Zootecnia, 39(9), 2081-2090. https://doi.org/10.1590/S1516-35982010000900029

Lopes, A. S. et al. (2007). Relationship of pre-ovulatory follicle size, estradiol concentrations and season to pregnancy outcome in dairy cows. Animal Reproduction Science, 99(1-2), 34-43. https://doi.org/10.1016/j.anireprosci.2006.04.056

Lucy, M. C. (2001). Reproductive loss in high-producing dairy cattle: where will it end?. $\begin{array}{llll}\text { Journal of Dairy } & \text { Science, } & \text { 84(6), } & \text { 1277-1293. }\end{array}$ https://doi.org/10.3168/jds.S0022-0302(01)70158-0

Luz, G. B. et al. (2018). Effects of the Bull on Conception Rate of Dairy Cows in Different Seasons and According to AI Type.Acta Scientiae Veterinariae, 46, 6. https://doi.org/10.22456/1679-9216.82554

Martin, G. B. (1984). Factors affecting the secretion of luteinizing hormone in the ewe. Biological Reviews, 59, 1-87.

Melo, P. C. H. et al. (2012). Fixed timed artificial insemination (FTAI) through progestagen (CIDR) of 1st, 2nd, 3rd and 4th uses in bovine: II. Conception rate related to times of CIDR use, to the semen used, to artificial insemination technician and to farm management. Livestock Research for Rural Development, 24(4), 1-8.

Meneghetti, M. et al. (2009). Fixed-time artificial insemination with estradiol and progesterone for Bos indicus cows I: basis for development of protocols. Theriogenology, 72(2), 179-189. https://doi.org/10.1016/j.theriogenology.2009.02.010

Meneghetti, M., \& Vasconcelos, J. L. M. (2008). Calving date, body condition score, and response to a timed artificial insemination protocol in first-calving beef cows. Arquivo 
Brasileiro de Medicina Veterinária e Zootecnia, 60(4), 786-793. https://doi.org/10.1590/S0102-09352008000400002

Neri, H. L. D. et al. (2015). Perfil de progesterona em novilhas com diferente atividade luteal e tratadas com implantes vaginais. Arquivo Brasileiro de Medicina Veterinária e Zootecnia, 67(2), 405-410. https://doi.org/10.1590/1678-7441

Parisi, A. M. et al. (2014). Molecular, cellular, and physiological determinants of bull fertility. Turkish Journal of Veterinary and Animal Sciences, 38(6), 637-642. https://doi.org/10.3906/vet-1404-76

Patterson, D. J. et al. (1995). Improved synchrony, conception rate, and fecundity in postpartum suckled beef cows fed melengestrol acetate prior to prostaglandin F2. Journal of Animal Science, 73(4), 954-959. https://doi.org/10.2527/1995.734954x

Pereira, L. L. et al. (2018). Effect of body condition score and reuse of progesterone-releasing intravaginal devices on conception rate following timed artificial insemination in Nelore cows. Reproduction in Domestic Animals, 53(3), 624-628. https://doi.org/10.1111/rda.13150

Perry, G. A. et al. (2005). Relationship between follicle size at insemination and pregnancy success. Proceedings of the National Academy of Sciences, 102(14), 5268-5273. https://doi.org/10.1073/pnas.0501700102

Perry, G. A. et al. (2007). Relationship between size of the ovulatory follicle and pregnancy success in beef heifers. Journal of Animal Science, 85(3), 684-689. https://doi.org/10.2527/jas.2006-519

Pilau, A., \& Lobato, J. F. P. (2009). Desenvolvimento e desempenho reprodutivo de vacas primíparas aos 22/24 meses de idade. Revista Brasileira de Zootecnia, 34(4), 728-736. https://doi.org/10.1590/S1516-35982009000400020

Pratt, S. L. et al. (1991). Luteal function, estrous response, and pregnancy rate after treatment with norgestomet and various dosages of estradiol valerate in suckled cows. Journal of Animal Science, 69(7), 2721-2726. https://doi.org/10.2527/1991.6972721x

Rhodes, F. M. et al. (2002). Effect of treatment with progesterone and oestradiol benzoate on ovarian follicular turnover in postpartum anoestrous cows and cows which have resumed oestrous cycles. Animal Reproduction Science, 69(3-4), 139-150. https://doi.org/10.1016/S0378-4320(01)00141-5

Roberson, M. S. et al. (1989). Luteinizing hormone secretion and corpus luteum function in cows receiving two levels of progesterone. Biology of Reproduction, 41(6), 997-1003. https://doi.org/10.1095/biolreprod41.6.997

Sawyer, G. J., Barker, D. J., \& Morris, R. J. (1991) Performance of young breeding cattle in commercial herds in the south-west of Western Australia. 2. Liveweight, body condition, timing of conception and fertility in first-calf heifers. Australian Journal of Experimental Agriculture, 31(4), 431-441. https://doi.org/10.1071/EA9910431 


\section{Macrothink}

Schenatto, R. O. et al. (2016). Impacto no desempenho de touros nos programas de IATF. Reunião Anual da Sociedade Brasileira de Tecnologia de Embriões. Foz do Iguaçu, Anais...2016, 234. [Online] Available: <http://itarget.com.br/newclients/sbte.org.br/2014/anais/anais2016.pdf (February 21. 2018)

Severo, N. C. (2009). Influência da qualidade do sêmen bovino congelado sobre a fertilidade. $A$ Hora Veterinária, 28(167), 36-39.

Silva, C. B. et al. (2015). Efeito do touro sobre a ocorrência de prenhez de fêmeas submetidas à IATF. Fórum de ensino pesquisa extensão e Gestão. In: $9^{\circ}$ Fórum de Ensino, Pesquisa, Extensão e Gestão (Montes Claros, Brasil), 202.

Souza, A. L. B. et al. (2015). Timed artificial insemination (TAI) based on CIDR first, second or third use in Bos indicus cows. Archives of Veterinary Science, 20(4), 82-87.

Spitzer, J. C. et al. (1995). Reproductive responses and calf birth and weaning weights as affected by body condition at parturition and postpartum weight gain in primiparous beef cows. Journal of Animal Science, 73(5), 1251-1257. https://doi.org/10.2527/1995.7351251x

Wheaton, J. E., \& Lamb, G. C. (2007). Induction of cyclicity in postpartum anestrous beef cows using progesterone, GnRH and estradiol cypionate (ECP). Animal Reproduction Science, 102(3-4), 208-216. https://doi.org/10.1016/j.anireprosci.2006.11.006

\section{Copyright Disclaimer}

Copyright for this article is retained by the author(s), with first publication rights granted to the journal.

This is an open-access article distributed under the terms and conditions of the Creative Commons Attribution license (http://creativecommons.org/licenses/by/4.0/). 